\title{
VLDLR wt Allele
}

National Cancer Institute

\section{Source}

National Cancer Institute. VLDLR wt Allele. NCI Thesaurus. Code C115014.

Human VLDLR wild-type allele is located in the vicinity of 9p24 and is approximately $33 \mathrm{~kb}$ in length. This allele, which encodes very low-density lipoprotein receptor protein, is involved in lipoprotein metabolism and the reelin signaling pathway. Mutation of the gene is associated with cerebellar hypoplasia and mental retardation with or without quadrupedal locomotion 1. 